ROCZNIKI TEOLOGICZNE

Tom LXVII, zeszyt 5 - 2020

DOI: https://doi.org/10.18290/rt20675-7

KS. RADOSŁAW KIMSZA

\title{
ARCHITEKTURA I SZTUKA LITURGICZNA JAKO ANTIDOTUM NA DESAKRALIZACJE. STUDIUM TWORCZOŚCI ARTYSTYCZNEJ M.I. RUPNIKA SI
}

\author{
ARCHITECTURE AND LITURGICAL ART \\ AS AN ANTIDOTE TO DESACRALIZATION. \\ A STUDY OF ARTISTIC CREATIVITY BY M.I. RUPNIK SI
}

\begin{abstract}
Contemporary architecture and sacred art have lost their original instinct in favor of illegible and ambiguous forms. In this way, sacred art, in a sense, sent the message to be a reality that helps man in contact with God, or, as the theorists of sacred art wanted, a tool that brings God down to earth. These tendencies are being remedied by Fr. Marko I. Rupnik, a Slovenian Jesuit, theologian and iconographer, founder of the Aletti Center - an institute of theology and art, promoting the idea of "the Christian breathing of two lungs", combining the Eastern and Western traditions, which formed the doctrine of the undivided Church. The effect of Rupnik's theological thought is liturgical art, which, inscribed in architecture, creates a space for human meeting with God.
\end{abstract}

Key words: sacred architecture; liturgical art; icon; Christian East; Eastern spirituality.

Architektura sakralna, w odróżnieniu od innych jej dziedzin, nie pełni funkcji jedynie użytkowej czy estetycznej. Także nie tworzy tylko przestrzeni gromadzenia się ludzkich zbiorowości w określonym celu, zazwyczaj dla sprawowania kultu religijnego. W swej istocie, w każdym detalu, winna być podporządkowana misterium fidei - tajemnicy wiary. Nie jest więc tylko czymś, ale odnosi się w sobie do Kogoś, ma organiczny wręcz związek z celebrowaną w niej liturgią - akcją uobecniającą wydarzenie Odkupienia człowieka i zapowiadającą udział odkupionego człowieka w liturgii niebiańskiej.

Studium współczesnych form architektonicznych w obrębie sacrum, jak również sztuk plastycznych wypełniających ich wnętrza, wskazuje w dużej mierze

Ks. dr hab. RAdOSŁAw KIMSZA, prof. PB, Pracownia Historii Architektury i Konserwacji Zabytków, Instytut Architektury i Urbanistyki, Politechnika Białostocka, adres do korespondencji: ul. O. Sosnowskiego 11, 15-893 Białystok, e-mail: r.kimsza@icloud.com; ORCID: https://orcid.org/ 0000 -0002-8504-5616. 
na odstąpienie od jednoznaczności przeznaczenia wspomnianych obiektów, na korzyść swoistego ich „odduchowienia”, by nie powiedzieć „desakralizacji formy”. Dlatego przymiotnik „sakralny”, odnoszący się do architektury i sztuki, ustępuje architekturze i sztuce religijnej, profanum zaś przenika sacrum niemalże dążąc do jego unicestwienia.

Próbę tworzenia organicznej więzi pomiędzy architekturą i sztuką sakralną a tym, czemu służą - celebracji liturgicznej, podejmuje od lat rzymskie atelier Centrum Aletti założone przez słoweńskiego jezuitę, teologa i ikonografa o. Marka I. Rupnika. Tworzona tam sztuka, w zamiarze Rupnika, ma odpowiadać istocie liturgii, tworzyć w swoich formach syntezę z tym - czemu towarzyszy. W ten sposób powstała tzw. sztuka liturgiczna, tzn. przekraczająca swoimi formami czas i przestrzeń, tworząca komunię pomiędzy doczesnością i wiecznością, w którą chrześcijanin jest włączony od sakramentu chrztu, a którą wyraża w liturgicznych celebracjach.

Studium nad współczesnymi realizacjami architektury i sztuki sakralnej, w szczególności polskiej ${ }^{1}$, pozwala zauważyć znaczne odstąpienie od jej pierwotnego, teologiczno-metafizycznego ukierunkowania. Formy, którymi się posługuje, przemawiają za udekorowaną użytecznością, której towarzyszą niejednokrotnie przypadkowe przedmioty kultu.

Sztuka liturgiczna, czy też duchowość sztuki tworzonej przez Rupnika wskazuje, że ma ona sens tylko wówczas, gdy stanowi konstytutywny element liturgicznej celebracji. Innymi słowy architektura sakralna i wypełniające jej przestrzenie sztuki plastyczne czy ekspresyjne mają właściwy sens tylko wówczas, gdy są istotowo zjednoczone z liturgią. Oznacza to, że przestrzeń i to, co ją wypełnia, z zasady mają tworzyć syntezę z sprawowaną liturgią.

O sakralności sztuk plastycznych (fresków, mozaik, malowideł) decyduje nie tylko ich teologiczna treść, ale także odpowiadające jej medium, materia i barwa, jakimi posłużył się artysta w wyrażeniu chrześcijańskiej doktryny. Kryją one w sobie teologiczne znaczenie i dopełniają treści form wkomponowując się w właściwą miejscu obrzędowość. To więc, co z punktu widzenia teorii sztuki ma jedynie wartość techniczną, medialną, podpadającą pod zmysły, w architekturze i sztuce sakralnej nabiera wymiaru duchowego, włącza się w liturgiczną akcję, nachyla niebo ku ziemi, albo staje się niebiańskim urządzeniem ziemi.

\footnotetext{
${ }^{1}$ Por. K. Popera, I. Cichonska, K. Snopek, Architektura VII dnia, Wydawnictwo Bęc Zmiana, Warszawa 2016.
} 


\section{KU TAJEMNICY WIECZNOŚCI}

Sprawowana w świątyniach chrześcijańskich dwóch tradycji wschodniej i zachodniej liturgia za pomocą materii, gestu i słowa wyraża duchowe życie człowieka. Jest odpowiedzią, skonstruowaną przy pomocy dostępnych zmysłom form, na inicjatywę Boga. Ma więc ona charakter teologiczno-antropologiczny. To, co Boskie, spotyka się w niej z tym, co ludzkie. $\mathrm{Z}$ tego względu liturgia nie jest rzeczywistością statyczną tylko dynamiczną, pulsującą życiem Boga i człowieka. Dlatego, będące z punktu widzenia fizycznego jedynie materią, świątynne mury ożywają wiarą twórcy wyrażoną w artystycznej koncepcji. I nie jest to jedynie metafizyczna koncepcja życia twórcy pomieszczonego w tworzonych przezeń formach. W sztuce sakralnej chodzi o ożywienie materii, o dynamizm ukierunkowany na udział w wewnętrznym życiu Trójcy Świętej: „Na ten świat miłość zstąpiła z miłości i przybrała kształt piękna"² w najpiękniejszym z synów ludzkich (por. Ps 45,3). Stąd sztuka sakralna skłania się do wydarzenia Jezusa Chrystusa z wszystkim, co je wypełnia. W Nim odnajduje swój punkt centralny. I dlatego człowiek z całą swoją historią, z doświadczeniem życia, przekracza granicę pomiędzy sacrum i profanum. Dzięki sztuce wchodzi w świat Boga, uczestniczy w nim nie jako bierny widz, ale uczestnik boskiej natury, „Bóg stał się człowiekiem po to, by człowiek stał się Bogiem”. Dlatego w obcowaniu ze sztuką sakralną człowiek wchodzi w życie Boga. W zamiarze twórcy sacrum nie tyle chodzi, by odbiorca miał doświadczenie estetyczne, ale by jak w liturgii doświadczał obecności i nią się przemieniał. W ten sposób sztuka i architektura sakralna stają się składową liturgii. Nie są obok niej, ale w niej. Nie tworzą liturgicznej scenografii, ale są częścią liturgicznej akcji. Jeśli liturgia ma charakter anamnetyczny nie $\mathrm{w}$ znaczeniu zwykłego przypomnienia wydarzenia z przeszłości, ale jego uobecnienia, to taką samą funkcję pełni sakralna forma plastyczna, bryła architektoniczna, śpiew, barwa, czy zapach kadzidła. Teologia liturgii i sztuka liturgiczna przeprowadzają w wierze przez granicę doczesności i wprowadzają w wieczność w Bogu.

Stworzona przez Rupnika sztuka liturgii czepie z kondycji poznawczej współczesnego człowieka. Nie jest to poznanie pojęciowe, wydedukowane z dostępnych rozumowi przesłanek. Wydaje się, że podstawą poznania dzisiejszego człowieka jest obraz, barwa, ruch. Mówią one i w dużej mierze kreują współczesny światopogląd. Stąd jednym z zadań współczesnych twórców sztuk sakralnych jest odnalezienie form, które przemówią do ich odbiorcy i wprowadzą w właściwą im treść. Jest to swoista inkulturacja przedmiotu wiary w sztukę po

\footnotetext{
${ }^{2}$ Cyt. za: Z. KrysiewiCZ, Sztuka sakralna uciemiężona, „Teofil” 2000, nr 3, s. 5.
} 
to, by ta pierwsza stawała się bardziej czytelna i nie przekraczając granicy poznania empirycznego wprowadziła w poznanie misterium inne od „mędrca szkiełka i oka”.

Zamiar twórczości Rupnika i jego szkoły wydaje się być jeden: pokazanie przedmiotu wyznawanej przez chrześcijan wiary nie jako skostniałej, martwej tkanki minionych czasów, ale wciąż żywej, pociągającej pięknem i komunią.

W takim rozumieniu sztuki widoczne są dwa nurty filozoficzno-teologiczne, z których czerpie Autor. Pierwszy to myśl P. Florenskiego, według którego prawda objawiona to miłość, a miłość urzeczywistniona to piękno. Piękno jest więc przeniknięte miłością, a ta możliwa jest tylko w komunii osób ${ }^{3}$.

Drugim wydaje się być eklezjologia T. Spidlika, widzącego Kościół jako pielgrzymujący Lud Boży, komunię osób w drodze ku pełni zjednoczenia z Bogiem W świecie, skazującym człowieka na samotność albo wirtualną relacyjność, wizja Kościoła jako wspólnoty odnajdującej swoje dopełnienie w wieczności w Bogu wydaje się być pociągającą, wypełniającą pustkę wykreowaną w człowieku przez świat.

Liturgia jest objawianiem się Boga człowiekowi w Bosko-ludzkiej naturze Jezusa Chrystusa. Przypomniał o tym Sobór Watykański II w Konstytucji Sacrosanctum Concilium: „Aby urzeczywistnić tak wielkie dzieło, Chrystus jest obecny zawsze w swoim Kościele, zwłaszcza w czynnościach liturgicznych. Jest obecny w ofierze Mszy świętej tak w osobie celebrującego, gdyż 'Ten sam, który kiedyś ofiarował siebie na krzyżu, obecnie ofiaruje się przez posługę kapłanów', jak zwłaszcza pod postaciami eucharystycznymi. Jest obecny swoją mocą w sakramentach, tak że gdy ktoś chrzci, sam Chrystus chrzci. Jest obecny w swoim słowie, bo gdy w Kościele czyta się Pismo Święte, On sam przemawia”.5. Liturgia jest więc szansą na przyjęcie ofiarującego się człowiekowi Boga w pełni prawdy, „Boga obiektywnego”, niejednokrotnie w wizji całkowicie różnej od „Boga subiektywnego”, stworzonej i kultywowanej w świadomości człowieka.

Ostatecznie w wizji Rupnika liturgia ma w sobie dwa wymiary: przedmiotowy, niezmienny, transcendujący, przekraczający miejsce i czas - Boski i podmiotowy, zmienny, pomieszczony w miejscu i czasie - ludzki. Inaczej w liturgii staje się spotkanie Boga z człowiekiem. Tak też winno być w sztuce liturgicznej: to, co samo w sobie jest obiektywne - misterium odkupienia, spotyka się z odkupionym

\footnotetext{
${ }^{3}$ P. Florenski, Filar i podpora prawdy. Próba teodycei prawostawnej w dwunastu listach, Wydawnictwo KR, Warszawa 2009, s. 64.

${ }^{4}$ T. SPIDLIK, Katechezy o Kościele, Wydawnictwo Ojców Franciszkanów „Bratni Zew”, Kraków 2003, s. 61.

${ }^{5}$ Sobór Watykański II, Konstytucja o liturgii świętej „Sacrosanctum Concilium”, w: SobóR WATYKański II, Konstytucje. Dekrety. Deklaracje. Tekst polski - nowe tłumaczenie, Pallottinum, Poznań 2002, s. 50.
} 
wpisanym w kategorię miejsca i czasu oraz związaną z nimi kulturę. W ten sposób sztuka liturgiczna jednoczy wieczność z doczesnością, staje się spotkaniem Boga z człowiekiem. Wypełnia ją treść, która z jednej strony współbrzmi z doktryną eklezjalną w jej wspólnotowym wymiarze, $\mathrm{z}$ drugiej pozostawia miejsce bardzo osobistej, indywidualnej interpretacji, intymnemu, Bosko-ludzkiemu spotkaniu 6 .

\section{KU CHRZEŚCIJAŃSKIM KORZENIOM WSCHODU I ZACHODU}

Sztuka liturgiczna, tworzona przez Rupnika i założone przez niego Centrum Aletti, wypełnia przestrzenie sakralne przede wszystkim rzymskokatolickie. Formy, za pomocą których wyraża teologiczne treści, już przy pierwszym zetknięciu tchną estetyką bizantyjską i zdają się bardziej wschodnie niż zachodnie. W efekcie mamy do czynienia z sztuką niepodzielonego Kościoła, która uniwersalne chrześcijaństwu treści pokazuje przy pomocy sztuki wschodniej, a te właściwe tradycji łacińskiej przetwarza na bardziej mistyczną od zachodniej sztukę bizantyjską.

Mistycyzm wschodniej sztuki sakralnej wspiera się o symbol i koloryt. Teologiczne treści, zapisane w traktatach Kościoła łacińskiego, na chrześcijańskim Wschodzie zostały uwiecznione za pomocą układu linii i barw na nieodłącznych liturgii ikonach. Ikonostas, a przynajmniej ikony Pantokratora i Theotokos są wpisane w liturgiczne kanony Wschodu. W nich zapisany jest nie tylko dogmat, jako przedmiot chrześcijańskiej wiary, ale także osobiste doświadczenie duchowe ikonografa, którym dzieli się z tym, który staje przed ikoną, by poprzez kontakt z prototypem, treścią ikonograficznego przedstawienia, dojść do typu, poprzez to, co widzialne, spotkać się z Niewidzialnym.

Sztuka Rupnika jest więc efektem starożytnego widzenia wyrażonego za pomocą zrozumiałego współczesnemu człowiekowi języka sztuki, spojrzeniem starożytnego ikonografa przetworzonym na język współczesnego obrazu. Językiem tym wyrażona zostaje obiektywność liturgii, jej sprzężenie z biblijnymi wydarzeniami, przede wszystkim z wydarzeniem Jezusa Chrystusa. W rezultacie materia staje się komunikatorem ducha, niejako „odmaterializowuje” się, pokazuje niewidzialne, uobecnia wieczne. Taka sztuka jest swoistą fuzją zachodniej bezpośredniości, materialności z bizantyjskim mistycyzmem, niedostępnością, skrytością.

\footnotetext{
${ }^{6}$ M. RUPNIK, Il simbolo dà accesso al mistero del mondo, w: T. SPIDLIK, M.I. RUPNIK, Una conoscenza integrale. La vita del simbolo, Lipa Edizioni, Roma 2010, s. 247.
} 


\section{KU PROSTOCIE PRZEDSTAWIEŃ}

Próba ukazania genezy inspiracji artystycznych realizacji Centrum Aletti prowadzi do sztuki sakralnej wczesnego Bizancjum, przedromańskiej i romańskiej. Uwidacznia to prostota przedstawień tego, co stanowi tajemnicę wiary wyrażoną w liturgii. Piękno wspomnianych epok było uwarunkowane objawieniem tajemnicy wiary. Jej interpretacja musiała dokonywać się z poszanowaniem rzeczywistego obrazu i jednoczesnym odniesieniem do życia człowieka epoki. Sztuka ta nie rozpraszała zbytnim koncentrowaniem się na detalu ani nie pełniła funkcji dekoracyjnej. Skupiała się natomiast na istocie przedstawienia, na komunikacji związanej z nim treści i uobecnieniu tego, co wyrażała. Stąd była to sztuka nie tyle narracyjna, co przede wszystkim objawiająca obecność tajemnicy.

Takie inspiracje przyświecają Rupnikowi w tworzeniu sztuki liturgicznej. Nie jest więc ona zrelacjonowaniem wydarzenia z przeszłości. Człowiek obcując z taką sztuką uświadamia, że świat poprzez wydarzenia historiozbawcze wciąż się przemienia. Obraz przekazuje wiarę, a pomieszczony w nim dogmat (doktryna) staje się bardziej dostępny ludzkiemu poznaniu.

Charakterystyczną cechą twórczości Rupnika są przestrzenie wolne od jakiejkolwiek narracji, wypełnione jedynie barwami tworzącymi abstrakcyjne formy, jakby pozbawione treści. W zamiarze artysty mają one stworzyć w sercu widza stan gotowości na przyjęcie zapisanego w prezentowanych wydarzeniach słowa. Przestrzenie niefiguratywne zajmują więc oko, zwracają na siebie uwagę, zatrzymują spojrzenie, by dokonało się w nim swoiste katarsis poprzedzające właściwe, obiektywne, ale i bardzo osobiste odczytanie treści obrazu.

W jednej z ostatnich realizacji Rupnika, kaplicy kolegium Montserrat w Barcelonie (2019 r.) ewangeliczną scenę z początku działalności Jezusa (Mt 4,12 nn.) wypełnia w zdecydowanej większości tło, które niejako podprowadza do wydarzenia, ale na nim nie zatrzymuje, kontynuuje drogę, by jej cel osiągnąć w Eucharystii ${ }^{7}$ „otulonej” tłem zmieniającym układ z horyzontalnego na wertykalny, symbolizujący właściwy kierunek ludzkiego istnienia, liturgię innego, ponadczasowego wymiaru. Materia tła, światło złota, wspomagane zewnętrzną, sztuczną energią, paleta barw, lśniące kamienie tworzą płaszczyznę przyjazną ludzkiemu spojrzeniu. Towarzysząca temu harmonia, w myśl zasady estetycznej „byty różnorodne, połączone w jedno są wyrazem życia”, tworzy wrażenie materii ożywionej. Zgodność elementów i ich harmonia symbolizują miłość, bowiem tylko ona jest w możności stworzenia komunii w różnorodności. Oto dlaczego tło, towarzyszące wydarzeniu

\footnotetext{
${ }^{7}$ https://www.centroaletti.com/opere/collegio-montserrat-a-barcellona/
} 
z mozaiki barcelońskiej kaplicy, doprowadziło do miejsca przechowywania Eucharystii - tabernakulum.

Sztuka liturgiczna M.I. Rupnika przezwycięża desakralizację współczesnego świata, która w dużej mierze opanowała także sztukę i architekturę sakralną. Tam, gdzie jest, tworzy swoistą, niebiańską enklawę, zapraszającą do udziału w życiu Boga. Dzięki jego twórczości wierzący nie idzie do kościoła, by uczestniczyć w Mszy św., ale przekraczając próg świątyni, stając pośrodku pulsujących życiem Boga ścian już jest uczestnikiem misterium wiary, a akcja liturgiczna jest jego istotowym dopełnieniem.

\section{BIBLIOGRAFIA}

FloRenski P., Filar i podpora prawdy. Próba teodycei prawostawnej w dwunastu listach, Wydawnictwo KR, Warszawa 2009.

KRYSIEWICZ Z., Sztuka sakralna uciemiężona, „Teofil” 2000, nr 3, s. 5-11.

SobÓR WATYKAŃSKi II, Konstytucja o liturgii świętej „Sacrosanctum Concilium”, w: SOBÓR WATYKAŃSKI II, Konstytucje. Dekrety. Deklaracje. Tekst polski - nowe ttumaczenie, Pallottinum, Poznań 2002, s. 48-78.

Popera K., I. Cichonska, K. SNOPEK, Architektura VII dnia, Wydawnictwo Bęc Zmiana, Warszawa 2016.

RUPNIK M., Il simbolo dà accesso al mistero del mondo, w: T. SPIDLIK, M.I. RUPNIK, Una conoscenza integrale. La vita del simbolo, Lipa Edizioni, Roma 2010, s. 193-270.

SPIDLIK T., Katechezy o Kościele, Wydawnictwo Ojców Franciszkanów „Bratni Zew”, Kraków 2003. https://www.centroaletti.com/opere/collegio-montserrat-a-barcellona/ (10.09.2020 r.).

\section{ARCHITEKTURA I SZTUKA LITURGICZNA JAKO ANTIDOTUM NA DESAKRALIZACJĘ. STUDIUM TWÓRCZOŚCI ARTYSTYCZNEJ M.I. RUPNIKA SI}

\section{STRESZCZENIE}

Współczesna architektura i sztuka sakralna zatraciły swoje pierwotne ukierunkowanie na korzyść nieczytelnych i wieloznacznych form. W ten sposób sztuka sakralna, w pewnym sensie, przesłała być rzeczywistością pomagającą w kontakcie człowieka z Bogiem, albo jak chcieli teoretycy sztuki sakralnej, narzędziem sprowadzającym Boga na ziemię. Tendencjom tym próbuje zaradzić o. Marko I. Rupnik, słoweński jezuita, teolog i ikonograf, założyciel Centrum Aletti - instytutu teologii i sztuki, promującego ideę „,chrześcijańskiego oddechu dwóch płuc”, łączenia tradycji wschodniej i zachodniej, jaka tworzyła doktrynę niepodzielonego Kościoła. Efektem myśli teologicznej Rupnika jest sztuka liturgiczna, która - wpisana w architekturę - tworzy przestrzeń spotkania się człowieka z Bogiem.

Słowa kluczowe: architektura sakralna; sztuka liturgiczna; ikona; chrześcijański Wschód; duchowość wschodnia. 